\title{
The effectiveness of the 4MAT teaching model upon student achievement and attitude levels
}

Uyangör, Sevinç Mert $\bowtie$

Balıkesir University, Balıkesir, Turkey (smert@balikesir.edu.tr)

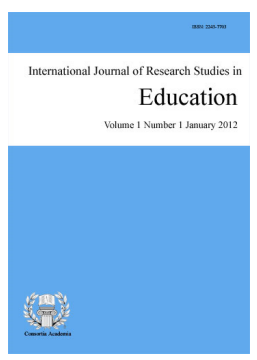

ISSN: $2243-7703$

Accepted: 25 January 2012 Online ISSN: 2243-7711

\section{Abstract}

4MAT is an 8-step, sequential instructional model based on two theoretical constructs: Kolb's model of learning styles and the concept of brain hemisphericity. The model, developed by B. McCarthy (1987) is derived by interacting each of Kolb's four quadrants with both left and right brain. The purpose of this study is to examine the influence of the 4MAT teaching model which depends on learning styles that have been generated by the help of the relationship between the brain and learning; and focuses on the learning loop as a centre upon students' level of mathematics course achievement; and the level of attitudes towards mathematics in the unit of the Hoop and Circle. An experimental pattern model with a pre-test, post-test control group has been used in this research. The sample of this study comprised 81 students from the 7th grade at Public School in Balıkesir during the 2009-2010 education periods. It has been determined that 4MAT method of instruction was more efficient than the traditional method.

Keywords: 4MAT teaching model; learning style; mathematics teaching; Hoop and Circle 


\section{The effectiveness of the 4MAT teaching model upon student achievement and attitude levels}

\section{Introduction}

Education of mathematics includes studies in the process of learning and teaching mathematics. All the activities in that process depend on the acquisition of mental skills (Hatfield, Edwards \& Bitter, 1997). Most of the mathematical concepts are abstract requiring high levels of cognitive activity. In the traditional classroom environment, the subject to be learnt is not individualized and the attention of the students is not drawn to the subject. It should be admitted that more concrete and less abstract concepts are learnt more easily (Baki, 2002). Furthermore, Ersoy (1997) remarks that individuals have some problems with their forms of perceiving mathematics. The fact that the students have problems with perceiving mathematical concepts and operating them brings about a low level of success in mathematics. Consequently, the implementation of theories dependent on cognitive basis in mathematics courses is considered to be more effective than the traditional method.

Some of the theories relying on cognitive basis depend on the individual differences and learning styles of the students. Since the 1940s, many models of learning styles have been defined. Some of those are the domain-dependent domain-independent styles, Gregorc model of learning style, Dunn model of learning style, Kolb model of learning style, and 4MAT. Each of these models of learning styles emphasizes one of several different dimensions, namely, cognitive, affective, and physiological (Cornet, 1983). The cognitive dimension emphasizing the perception and operation of knowledge has a crucial importance for teaching mathematics (Başıüuük, 2004). According to Babadoğan (2000), if the learning styles of the individuals are determined, how the individuals learn and what kind of teaching design should be implemented for them can be grasped more easily. Thus, according to these styles, the teacher can organize appropriate teaching environments for both himself and the students. There are many studies demonstrating that matching the teaching styles with the learning styles has proved to be influential in student success (Scales, 2000). Therefore, we think that the teaching models depending on cognitive dimension and learning styles will be successful in teaching mathematics. In this study, the influences of geometry teaching implemented depending on the 4MAT teaching model were examined as the students have some problems with perception and operation of knowledge in mathematics courses .Both perception and operation of knowledge constitute the foundation of McCarthy's model of learning style.

\subsection{MAT Teaching Model}

4MAT (4 Mode Application Techniques) is a model which changes the learning style concepts into educational strategies. It was developed by Bernice McCarthy in the 1970s. This model depends on the experimental learning theory in the outcomes of Kolb's (1984) research of the brain hemispheres. Even though Kolb (1984) have depended his learning theory on management and experimental studies, he has depended its form on the ideas of the theorists who progressed step by step and influenced the educational thought. Kolb developed his complex learning theory depending on living by uniting the elements in Dewey, Lewin, Piaget, and Vygotsky's studies. Kolb's aim is to establish the meaningful connections between theory and practice by focusing on research in understanding how social life affects cognitive activities. Because he is specialized in management and organizational systems, most of his studies have been conducted in how the individuals get and develop the information (Kolb, 1984).

Moreover, as a result of the studies that he has carried out in Lewin's subjective experience, Kolb has concluded that emotions are as effective as thoughts during the learning process. In the basis of Kolb's theory, Piaget takes part in addition to Lewin. Kolb has used Piaget's studies into how the intelligence develops as a 
The effectiveness of the 4MAT teaching model upon student achievement and attitude levels

result of the interaction between the individuals and their environments. Kolb adapted Jung's type system to his theory so as to determine the limits of implementation in learning in a detailed way and to make the implementation easy. After all these studies, Kolb has examined the learning styles in four types; divergers, convergers, accommodators and assimilators. McCarthy has depended his learning model for primary and middle education on the learning styles that Kolb has examined in those four types (Ojure, 1997).

At the same time, McCarthy has been influenced by studies about the brain hemispheres. McCarthy supports the idea that especially two results of these studies are directly related to education: The first one is that studies of the brain hemispheres show that different lobes have different functions. The two lobes have different skill areas and react to different stimuli although they always work together. Secondly, McCarthy supports that the differences in application of neutral system causes the emergence of the individual differences, as well. Also, these findings have supported the research results of Gregorc, Jung, and Kolb. As a result of his research, McCarthy classified the learning styles as follows; Type 1: Innovative Learners, Type 2: Analytic Learners, Type 3: Common Sense Learners, Type 4: Dynamic Learners (Ojure, 1997; Kelly, 1990; McCarthy, 1987).

McCarthy has remarked that the individuals perceive and operate the information in different ways. The forms of individuals' perception of the information are their abilities of concrete experiences and abstract conceptualization. In the new learning situations, directly concentrating on their concrete experiences, some individuals perceive the information by sensing and feeling. In the operation of information, the skills of active experience and reflective observation are significant. Some individuals operate (clusters) the information by watching and some of them by doing and applying (Peker, 2003).

The 4MAT teaching model relies upon the learning loop which includes the four types of students introduced by McCharthy and the right and left hemispheres of the brain which makes learning a constant process. In addition, Hebb, who has managed brain based studies before, has also mentioned the existence of this kind of learning loop. McCharthy divides this loop that he calls the 4MAT impeller into eight steps and designs it as a process that is made up of activities which are appropriate for the four types of students. McCharthy names this loop the "natural learning stage". In this loop, while the teachers are going around the impeller, they teach according to personal differences by utilizing the educational strategies that are appropriate for each student. Consequently, teachers should design in a frame which encompasses the loop wholly and considers the individual differences (McCarthy \& McCarthy, 2003, 2006; Ballone \& Czerniak 2001).

The 4MAT teaching model is actually defined as a beyond-model because it is a way of organizing around the concept that should be acquired by taking the elements of knowledge into the center. Moreover, this model is considered to be appropriate to construct other educational operations such as Bloom's Taxonomy and cooperative learning. Indeed, successful implementation of 4MAT requires the teachers to be aware of several learning strategies. The teachers should form their conceptual objectives, hold respect for the differences of the students and arrange a classroom environment that will take them to the essence of the concept (McCarthy \& McCarthy, 2003). Hence, McCarthy claims that 4MAT can be applied best provided that the skills of the teachers are developed and the education is structured in a way that is suitable for multiple methods so that the students will receive every style of leaning (McCarthy \& Leflar, 1983). The fact that he puts forward that Jung's type theory constitutes a bond between learning and teaching styles has made him design his measure of learning type in order to understand teachers' personal styles. The 4MAT system has two important priorities. The first one is: "That human beings have got learning styles and preferences to make half hemispheric operations". The second one is: "Designing and using multiple educational strategies in a systematic environment so as to teach these preferences can develop teaching and learning" (B1kmaz, 2002).

The compositions that are made up of the techniques of perceiving and operating knowledge constitute your learning style. We have remarked before that McCarthy has four important learning styles that he defined similar to the Kolb learning style. These learning styles all have equal values. Students want to be informed about the learning style they are receiving (McCarthy \& McCarthy, 2003, 2006; Ballone \& Czerniak, 2001). It is required 
to present teaching appropriately for each of the four learning styles so that they can develop other learning styles, use their own learning styles well and become successful.

All the students are in different places of the learning loop. In the 4MAT teaching model, the students move around the learning loop in a certain order. This order is in the form of a natural learning development. McCarthy asserts that the knowledge should be taught to the individuals who have four learning styles by using both the right and left mod operating techniques (Peker, 2003; McCarthy, 2000). The 4MAT teaching model has been designed in such a way that all four types of learners can find appropriate periods of time for themselves. That is to say, it aims to present a teaching designed by taking all these four learning styles into consideration. Ordinate of coordinate-axis is the dimension of perceiving the knowledge which determines how the knowledge is taken and perceived. Its abscissa is the dimension of operating knowledge which determines how the perceived knowledge is operated. According to McCarthy, the loop is more significant than one of its parts. We perceive the novelty first from our intuitions and the feelings we experience in life. Then, we tend to define, abstract and conceptualize what we perceived. We start using our conceptualized knowledge actively in our daily life (Peker, 2003; McCarthy, 2000). According to McCarthy the individuals perceive the knowledge and experiences in different methods and they operate this perceived knowledge and experience in different methods. In the 4MAT teaching model, the role of the teacher changes as s/he goes around the learning loop; the teachers should complete the learning process around the learning loop.

\subsection{The Purpose of the Study}

The basic objective of this research is to examine the influence of the 4MAT teaching model which depends on learning styles that have been generated by the help of the relationship between the brain and learning; and focuses on the learning loop as a centre upon students' level of mathematics course achievement; and the level of attitudes towards mathematics in the unit of the Hoop and Circle.

\subsection{The Significance of the Study}

Geometry is naturally a way of picturing the world in which we live. The improvement of Geometry depends on the development of spatial intelligence and the student's ability to see the necessary relationships. Classroom experiences concerning Geometrical relationships improve the judgmental capability of the students. An informal (not defined mathematical) approach to geometrical concepts in primary schools proves to be mathematically efficient because it provides students with an opportunity to improve logical thinking and deduction (Hacısalihoğlu, Mirasyedioğlu, \& Akpınar 2004).

When the importance of geometry is taken into consideration, among the things to be done, the most crucial is the improvement of geometry education. If the improvement of geometrical thinking is taken into account, it is thought that the students should construct the geometrical rules as if s/he was discovering them for the first time rather than endeavoring to apply the bulk of rules provided by their teachers. Hence, in this research, the student-centered 4MAT teaching model which depends on learning by doing-experience and which is believed to give this opportunity to the students has been utilized.

\subsection{Statement of the Problem}

Is there a significant relationship between the group for whom the 4MAT teaching model which takes learning styles of the students as its basis is applied, and the group for whom this model is not applied, in terms of the level of mathematics course achievement and level of their attitudes towards mathematics in the unit of Hoop and Circle?

1. Is there a significant difference between the mathematical course achievement levels of the experimental group for whom the 4MAT teaching model is applied and the control groups for whom a traditional teaching methods is applied? 
The effectiveness of the 4MAT teaching model upon student achievement and attitude levels

2. Is there a significant difference of attitudes towards mathematics courses between the experimental group for whom the 4MAT teaching model is applied and the control groups for whom traditional teaching is applied?

\section{Methodology}

An experimental pattern model with a pre-test, post-test control group has been used in this research. Before starting the experimental research, both of the groups have been applied a scale of pre-test and pre-attitude. In the research, a post test has been applied to all the students to whom the pre-test has been applied, and in this way, loss of subject is prevented. It is thought that the fact that there is not a significant difference between the two groups in terms of their pre-test and pre-attitude grades at the beginning of the study and that the groups are determined impartially removes the partial selection that prevents external validity.

For the purpose of determining the subjects, two equal sections consisting of 81 students from the 7 th grade at Public School in Balıkesir during the 2009-2010 education period have been included in the research by taking their grades in 1st into consideration, and from these two sections, randomly 7/A has been selected as the experimental group and 7/C as the control group. The subjects are 81 students from 7/A and 7/C classrooms in Public School who are equal groups in terms of their mathematics grades on their report cards. According to the result of one-way variance analysis of unrelated sampling carried out to compare the mathematics grades of 7/A and $7 / \mathrm{C}$ sections in the 1 st semester, no significant difference between the academic success of the students could be found prior to the application.

Prior to the application, some data related to the general attitudes of the students has been collected by applying the attitude scale for mathematics courses to the experimental and control groups. Also, according to the results of the t-test carried out to determine whether there is a significant difference between experimental and control groups in terms of the total grades of pre-attitude, there is not a significant difference between the levels of the pre-attitudes of the students in the control group and experimental group towards mathematics course.

\subsection{Data Collecting Tools}

The unit of Hoop and Circle and related pre-test and post-tests applied for the purpose of determining the effect of the 4MAT teaching model upon students' achievement at the 7th grade of Primary school, have been prepared by taking the subjects and related objectives and acquisitions into consideration by the researcher. The questions while developing the tests have been prepared by using the course book, the mathematics questions which were asked in LGS (High School Entrance Examination) and in the Private Schools examinations. While selecting the questions, aims and acquisitions related to in the unit of Hoop and Circle in the primary school mathematics program of Ministry of National Education (2007) have been taken into consideration. Experts have checked whether the selected program can measure the acquisitions in question or not. In accordance with the experts' opinions, 20 multiple questions appropriate for the aims and acquisitions have been prepared. For the validity and reliability of the questions, the test has been conducted to 78 8th grade students. From the findings of reliability analysis, 5 items whose total item correlations are below 0.30 have been taken out of the test. For the purpose of measuring the attitudes of the students towards the mathematics course, the "Mathematics Course Attitude Scale" that has been developed by Baykul (1990) has been used. The alpha reliability coefficient of the scale is 0.96 .

\subsection{Data Collecting Process and Analysis of Data}

In this part of the research, the processes followed to collect the data to find an answer for the sub-questions of the research are explained. So as to be able to start the experimental operations, a 4MAT experimental teaching program design that can be completed in 3 weeks has been prepared. The experimental teaching program designed according to the principles of the 4MAT teaching model has been submitted to the instructors 
at the departments of Mathematics education, program development in education and field teaching for comment. By evaluating the ideas and criticisms given by the departments the design has been finalized. After the trial applications of the measurement tools used in the research are completed, they are also finalized. The experimental operations have started with the provision of the mathematics course achievement grades of 7 th grade students in the 1 st semester from school administration records kept on computer. Among the 7/A and 7/C classes who are equal to one another in terms of mathematics course achievement grades in the 1st semester, 7/A is randomly determined as the experimental group, $7 / \mathrm{C}$ as the control group.

Not during the experiment period; the scale of attitude towards mathematics course before the experiment begins, has been applied to both the experiment group and the control group. The experiment group has been taught at a rate of 4 hours a week for 4 weeks according to the 4MAT teaching model, the control group has been taught with traditional methods. In the control group, a mathematics course book distributed to primary schools by the Ministry of National Education is used, and in the experiment group, from the content of the same book, activities appropriate for the 4MAT teaching model have been prepared and lesson plans appropriate for this model have been used. Following the experiment, the same measurement tools have been implemented again. The data collected according to the objective of the research has been analyzed with the SPSS-16.0 program on computer by using the statistical analysis techniques appropriate for the properties of data, and the findings obtained have been presented as figures.

\section{Findings}

To seek an answer to first sub-problem, the means of the pre and post achievement tests of the students in the experimental group and the control group have been compared in the groups and between the groups.

\section{Table 1}

The comparison of the Achievement Grades of Pre and Post Tests of the Experiment Group for whom the 4MAT

Teaching Model is applied, in the unit of Hoop and Circle

\begin{tabular}{ccccccccc}
\hline Group & $N$ & Test & Mean & Score & Mean difference & $S D$ & $\mathrm{t}$ & $p$ \\
\hline Experimental & 41 & Pre & 24.47 & 12.72 & 47.10 & 40 & -2.74 & .00 \\
& & Post & 71.57 & 11.91 & & & & \\
\hline
\end{tabular}

Note. $* p<.05$

As it is seen in Table 1, the students in the experimental group got an average of 24.47 points in the pre-test unit of Hoop and Circle; they got average 71.57 in the post test administered after the application. According to the results obtained, there is a 47.10 point difference in favor of the post test between the means of the grades that the students in the experimental group got in the pre and post achievement tests. This difference can be named as the average achievement grade that the students in the experimental group obtained in the unit of Hoop and Circle. The " $\mathrm{t}$ " value has proved to be significant according to the results of a paired t-test that has been conducted to learn the significance of the difference between these average grades that the students in the experiment group obtained in the pre and post tests $[\mathrm{t}=-2.74 ;(p=.00<.05)]$. Depending upon the findings, it can be said that the experimental program that has been constructed according to the 4MAT teaching model has been effective for the success of the students in the experiment group in the unit of Hoop and Circle.

As it is seen in Table 2, the students in the control group got an average of 26.75 points in the pre-test assessment in the unit of Hoop and Circle; they got an average of 58.91 points in the post test administered after the application. According to the results obtained, there is a 32.16 points difference in favor of the post test between the means of the grades that the students in the experiment group got in the pre and post achievement tests. This difference can be named as the average achievement grade that the students in the control group obtained in the unit of Hoop and Circle. " $t$ " value has proved to be significant according to the results of a paired $\mathrm{t}$ test that has been conducted to learn the significance of the differences between these average grades that the 
The effectiveness of the 4MAT teaching model upon student achievement and attitude levels

students in the control group obtained in the pre and post tests $[\mathrm{t}=-14.16 ;(p=.00<.05)]$. Depending upon the findings, it can be said that the experimental program that has been constructed according to the 4MAT teaching model has been effective for the success of the students in the experiment group in the unit of Hoop and Circle.

Table 2

The comparison of the Achievement Grades of Pre and Post Tests of the Control Group who have been taught traditionally using the course book, in the unit of Hoop and Circle

\begin{tabular}{ccccccccc}
\hline Group & $N$ & Test & Mean & Score & Mean difference & $S D$ & $\mathrm{t}$ & $p$ \\
\hline Control & 40 & Pre & 26.75 & 9.51 & 32.16 & 39 & -4.25 & .00 \\
& & Post & 58.91 & 13.28 & & & & \\
\hline
\end{tabular}

Note. $* p<.05$

Table 3

The comparison of the Achievement Grades of the students in the Experimental and the Control Groups in the Post Test

\begin{tabular}{llllcccc}
\hline \multicolumn{1}{c}{ Group } & $N$ & Mean & Score & Mean difference & $S D$ & $\mathrm{t}$ & $p$ \\
\hline Control & 40 & 58.91 & 13.28 & 12.66 & 79 & -1.34 & .00 \\
Experimental & 41 & 71.57 & 11.91 & & & & \\
\hline
\end{tabular}

Note. ${ }^{*} p<.05$

When the means in Table 3 are examined, the mean of post test grades of experiment group is 71.57; the post test mean of the control group control is 58.91. The post test grade mean of the experimental group is higher than the control group. Also, there is a difference of 12.66 points in favor of the experiment group between post test grades of both groups. According to the results of the t-test that has been conducted to learn the significance of the difference between the means of post test grades of experimental and control groups, it can be noticed that there is a significant difference between the means of average grades of the post test $[\mathrm{t}=-1.34 ;(p=.00<.01)]$. Depending on the fact that there is a significant difference between means of average grades of post test, the 4MAT teaching model applied to the experiment group has proved to be more effective than the traditional teaching model applied to the control group in regards to the students success in the unit of Hoop and Circle.

Table 4

The comparison of the Achievement Grades of Mathematics Course of Experimental and Control Groups

\begin{tabular}{llllcccc}
\hline \multicolumn{1}{c}{ Group } & $N$ & Mean & Score & Mean difference & $S D$ & $\mathrm{t}$ & $p$ \\
\hline Control & 40 & 32.16 & 13.72 & 14.94 & 79 & -1.88 & .00 \\
Experimental & 41 & 47.10 & 12.76 & & & & \\
\hline
\end{tabular}

Note. $* p<.05$

When we examine the means in Table 4 we see that the experimental group achieved a mean grade of 47.10 on their mathematics course whereas the control group achieved a mean of 32.16. There is a difference of 14.94 points in favor of the experimental group. The experimental groups post test grades also have a higher mean than the control groups. The " $t$ " test results conclude that there is a significant difference between the achievement grade means $[\mathrm{t}=-1.88 ;(p=.00<.05)]$. These results show that in regard to the students' course achievement grades the application of the 4MAT teaching model to the experimental group during the Hoop and Circle unit proved to be more effective than the traditional teaching model applied to the control group.

To solve the second sub-problem, the arithmetic-means of the pre and post attitude grades of the subjects in the experimental group and the control group have been compared in the groups and between the groups. 
Uyangör, S. M.

\section{Table 5}

The comparison of Attitude Grades in Pre and Post Tests assessing the Attitude Level of the students in the Experimental Group, to whom 4MAT Teaching Model has been applied, towards Mathematics course

\begin{tabular}{ccccccccc}
\hline Group & $N$ & Test & Mean & Score & Mean difference & $S D$ & $\mathrm{t}$ & $p$ \\
\hline Experimental & 41 & Pre & 117.71 & 28.30 & 12.31 & 40 & 1.68 & .001 \\
& & Post & 130.02 & 18.18 & & & & \\
\hline
\end{tabular}

Note. ${ }^{*} p<.05$

As can be seen in Table 5 in the pre-test, attitude levels of the students in the experiment group towards mathematics course is on average 117.71 points, in the post test it is on average 130.02 points. There is a 12.31 points difference in the favor of the post test between pre and post attitude grades of the students in the experimental group. This difference demonstrates the positive change in the attitude level of the students towards the experimental groups' mathematics course. According to the results of the paired t-test that has been conducted to learn the significance of the difference between the average grades of experimental group in pre and post tests, the " $\mathrm{t}$ " value has proved to be significant $[\mathrm{t}=1.68 ;(p=.001<.05)]$. Depending on the results obtained, it can be said that the experimental program planned according to the 4MAT teaching model has been effective in helping the students from the experimental group develop a positive attitude towards their mathematics course.

\section{Table 6}

The comparison of Attitude Grades in Pre and Post Tests assessing the Mathematics Course Attitude Levels of the Students in the Control Group, to whom a course book dependent Traditional Teaching Model depending on course book has been applied

\begin{tabular}{ccccccccc}
\hline \multicolumn{1}{c}{ Group } & $N$ & Test & Mean & Score & Mean difference & $S D$ & t & $p$ \\
\hline Control & 40 & Pre & 105.7 & 30.88 & 1.50 & 39 & 0.16 & .395 \\
& & Post & 107.2 & 29.25 & & & & \\
\hline
\end{tabular}

Note. ${ }^{*} p<.05$

As can be seen in Table 6 in the pre-test, attitude levels of the students in the control group towards mathematic courses has an average of 105.7 points, in the post test it has an average of 107.2 points. There is a 1.50 point difference in favor of the post test between pre and post attitude grades of the students in the control group. This difference demonstrates the positive change in the attitude level of the students in the control group towards mathematic courses. According to the results of paired t-test that has been conducted to learn the significance of the difference between the average grades of control group in pre and post tests, " $t$ " value has not proved to be significant $[\mathrm{t}=0.16 ;(p=.395>.05)]$. Depending on the results obtained, it can be said that the experimental program planned according to the 4MAT teaching model has not been effective to help the students in the control group develop a positive attitude towards mathematics course.

Table 7

The comparison of Grades of Experimental and Control Groups in the Post Test assessing the levels of their Attitudes towards Mathematic courses

\begin{tabular}{llllcccc}
\hline \multicolumn{1}{c}{ Group } & $N$ & Mean & Score & Mean difference & $S D$ & $\mathrm{t}$ & $p$ \\
\hline Control & 40 & 107.20 & 29.23 & 22.82 & 79 & -1.804 & .000 \\
Experimental & 41 & 130.02 & 18.18 & & & & \\
\hline
\end{tabular}

Note. $* p<.05$

When the means in Table 7 are examined, the post attitude mean of the experimental group is 130.02 points; 
The effectiveness of the 4MAT teaching model upon student achievement and attitude levels

the post attitude mean of the control group is 107.20. There is an average 22.82 points difference in favor of the experimental group. As a result of the "t" test that is carried out for independent measurements in order to learn whether this difference is significant or not, the " $\mathrm{t}$ " value has proved to be significant $[\mathrm{t}=-1.804 ;(p=.000<.05)]$. According to the obtained results, mathematics teaching planned according to the 4MAT teaching model applied to the experimental group is more effective than the traditional method applied to control group in changing the attitude level in a positive way.

\section{Table 8}

The comparison of Pre and Post Attitude points relating to the Attitude Levels of Experimental and Control Groups towards Mathematics course

\begin{tabular}{lccccccc}
\hline \multicolumn{1}{c}{ Group } & $N$ & Mean & Score & Mean difference & $S D$ & $\mathrm{t}$ & $p$ \\
\hline Control & 40 & 1.50 & 6.70 & 10.81 & 79 & -0.61 & .011 \\
Experimental & 41 & 12.31 & 20.63 & & & & \\
\hline
\end{tabular}

Note. ${ }^{*} p<.05$

When Table 8 is examined, we notice the attitude level of the students in the experimental group towards mathematic courses averages 12.31 , as opposed to 1.50 in the control group. There is a 10.81 point difference in favor of the experimental group in regards to their attitude level towards mathematic courses. As a result of the " $t$ " test carried out to learn whether this difference is significant or not, the " $\mathrm{t}$ " value has proved to be significant $[\mathrm{t}=-0.61 ;(p=.011<.05)]$. According to this result, the application of the 4MAT teaching model applied to the experimental group has proved to be more effective than the traditional teaching method in terms of changing the attitude level of the students towards their course in a positive manner.

\section{Results and Discussion}

The aim of this research is to examine the influence of the 4MAT teaching model which depends on learning styles that have been generated by the help of the relationship between the brain and learning; and focuses on the learning loop as a centre upon students' level of mathematics course achievement and the level of attitudes towards mathematics. As a result of the first sub-problem, there is a significant difference in favor of the experimental group between the achievement grades obtained by the subjects in the experimental and control groups in the pre and post applications. The studies examined in the literature made indicated that the learning styles and individual differences influence the learning and success of the learner considerably. Consequently, the necessity for the teachers to take the individuals different ability types into consideration during teaching is felt much more. The researchers support the positive effect of the teachers who apply a teaching model by taking learning styles into consideration upon the students' success (Uyangör \& Övez 2009; Orhun, 2007). The point that should not be forgotten here is that there is no difference or superiority between the learning styles.

Secondly, in the experimental study, according to the results of the analysis that has been carried out in order to learn whether there is a significant difference between the attitude levels of the students towards mathematics course in the experimental group to whom the 4MAT teaching model has been applied and in the control group to whom the traditional teaching has been applied, this result has been reached: there is a significant difference between the attitude levels of the students towards mathematics course in the experimental group and the control group. In addition, the mean of attitude grades of the students towards mathematics course in the experimental group is higher than the mean of attitude grades of the students towards mathematics course in the control group and the difference is in the favor of the experimental group.

The teaching provided depending upon the learning styles can affect the students' success and attitude in a positive way (Peker, 2003; Tatar \& Dikici, 2009; Uyangör \& Övez, 2009). So as to provide this effective learning environment, the teachers should create a teaching environment by taking all the learning styles into consideration rather than only one style. In this way, the students can benefit from the interests and capabilities 
of the individuals who have different learning styles. Before these stages, a pre-service and in-service training that will help the teachers to be able to use the teaching models depending on learning styles should be provided for them since it is highly crucial for the teachers, who have an active role in the implementation, to be able to conduct the implementation and plan it correctly. McCarthy supports this importance as well, and most of his studies are connected with the education of the teachers and administrative staff about this point.

\section{Conclusion}

We think that the 4MAT teaching model will have many contributions especially in teaching Mathematics and Geometry. Moreover, thanks to the 4MAT learning loop, the students will be able to comprehend the abstract mathematical concept that is one of the biggest problems for the students. In addition to that, the processes in the learning loop can be quite helpful for the students in regard to the use of mathematical and geometrical concepts in real life. The 4MAT teaching model provides the students with an opportunity to perceive knowledge and experience in a field starting from concrete experiences to abstract conceptualization. Therefore, the teachers can take the four learning styles into consideration in order to meet the needs of all the students. First of all, the teachers should learn the differences between the four learning styles. While maintaining to support the learning style of every student in their learning process, they should expose all of the students to multiple education techniques systematically. So as to fulfill teaching methods appropriate for different learning styles correctly, the mathematics teachers can include such student centered teaching models in the 4MAT loop as Problem Dependent Learning, Multiple Intelligence Theory, Brain Based Learning, Constructive Learning Theory, Project Based Learning, Research Based Learning, computer supported mathematics teaching and active learning.

\section{References:}

Babadoğan, C. (2000). Course design development focus learning styles [Öğrenme Stili Odaklı Ders Tasarımı Geliştirme], Milli Eğitim Dergisi, 147, 61-63.

Ballone, L. M., \& Czerniak, C. M. (2001). Teachers' beliefs about accommodating students' learning styles in science classes. Electronic Journal of Science Education, 6, 4-29.

Baki, A. (2002). Computer aided mathematics for learners and teachers [Öğrenenler ve Öğretenler İçin Bilgisayar Destekli Matematik]. Istanbul: Ceren Tanitım Ltd.

Başıüiyük, A. (2004). The learning styles that mathematics teachers can take into consideration: The model of McCARTHY [Matematik Öğretmenlerinin Dikkate Alabilecekleri Öğrenme Stilleri: Mccarty Modeli], Milli Ĕgitim Dergisi, 163.

Baykul, Y. (1990). Thoughts scale towards mathematics. Ankara: SYM Yayınları.

Bıkmaz, H. F. (2002). Translation: Bernice McCarty, educational leadership [Öğrenme Biçimlerini Okula Getirmede 4Mat Sistemini kullanma]. Ankara Üniversitesi Ĕgitim Bilimleri Fakültesi Dergisi, Cilt:34, Say1:1-2, 105-111.

Cornet, C. E. (1983). What you should know about teaching and learning styles. Bloomington, Indiana: Phi Delta Kapan.

Ersoy, Y. (1997). Trends in mathematics education [Matematik Eğitiminde Yönelişler] Çağdaş Eğitim. 22 (Mart/230), 11-13.

Hacısalihoğlu, H. H., Mirasyedioğlu, Ş., \& Akpınar, A. (2004). 6-8 primary mathematics teaching [İlköğretim 6-8 Matematik Öğretimi (Matematikte İsbirliğine Dayalı Yapılandırıcı Öğrenme ve Öğretme)]. Ankara: Asil Yayın Dağıtım.

Hatfield, M., Edwards, N., \& Bitter, G. (1997). Mathematics methods for elementary and middle school teachers. Boston: Allyn and Bacon.

Kelly, C. (1990). Using 4MAT in law school. Educational Leadership, 48(2), 40-41.

Kolb, D. A. (1984). Experiential learning: Experiences as the source of learning and development. Englewood Cliffs, NJ: Prentice Hall, Inc. 
The effectiveness of the 4MAT teaching model upon student achievement and attitude levels

Milli Eğitim Bakanlığı. (2007). The primary school mathematics program of ministry of national education [İlköğretim Matematik Dersi 6-8. Sınıflar Öğretim Programı]. Ankara.

McCarthy B., \& Leflar, S. (Eds.). (1983). 4MAT in action: Creative lesson plans for teaching to learning styles with right/left mode techniques. Barrington, IL: Excel, Inc.

McCarthy, B. (1987). The 4MAT system. Barrington, IL: Excel, Inc.

McCarthy, B. (2000). About teaching 4MAT in the classroom. Wauconda, IL: About Learning, Inc.

McCarthy, B., \& McCarthy, D. (2003). About teaching companion: The 4MAT implementation workbook (pp. 122-125). Wauconda, IL: About Teaching, Inc.

McCarthy, B., \& McCarthy, D. (2006). Teaching around the 4MAT cycle: Designing instruction for diverse learners with diverse learning styles. Thousand Oaks, CA: Corwin Press.

Ojure, L. (1997). An investigation of the relationship between teachers' participation in 4MAT fundamentals training and teachers' perception of teacher efficacy. Unpublished PhD Dissertation, Virginia Polytechnic Institute and State University.

Orhun, N. (2007). An investigation into the mathematics achievement and attitude towards mathematics with respect to learning style according to gender. International Journal of Mathematical Education in Science and Technology, 38(3), 321-333. <http://dx.doi.org/10.1080/00207390601116060>

Peker, M. (2003). The effects of learning styles and 4MAT education model on the students' achievements and attitudes [Öğrenme stilleri ve 4MAT Yönteminin Öğrencilerin Matematik Tutum ve Başarılarına Etkisi], Ankara: Unpublished PhD Dissertation, Gazi Üniversitesi Eğitim Bilimleri Enstitüsü.

Peker, M., \& Yalın, H. İ., (2003) Teaching mathematics based on learning styles [Öğrenme Stillerine Dayalı Matematik Öğretimi]. Türk Eğitim Bilimleri Dergisi, Cilt 1, Say1 4, 371-384.

Scales, A. Y. (2000). The effect of learning style, major, and gender on learning computer-aided drawing in an introductory engineering/technical graphics course. Unpublished PhD Dissertation, North Carolina State University.

Tatar, E., \& Dikici, R. (2009). The effect of the 4MAT method (learning styles and brain hemispheres) of instruction on achievement in mathematics. International Journal of Mathematical Education in Science and Technology, 40(8), 1027-1036. <http://dx.doi.org/10.1080/00207390903121750>

Uyangör, S. M., \& Övez, F. T. D. (2009). The effects of the 4MAT education model on the student achievements and learning style. Necatibey Faculty of Education Electronic Journal of Science and Mathematics Education, 3(2), 178-194.

Yenice, N., \& Saracaloğlu, A. S. (2009). The relationship between learning styles and science achivement of preservice elemantary school teachers [Sınıf Öğretmeni Adaylarının Öğrenme Stilleri ile Fen Başarıları Arasındaki İlişki]. Yüzüncü Yıl Üniversitesi, Eğitim Fakültesi Dergisi. Cilt:V1, Sayı:1, 162-173. 
Uyangör, S. M. 